Article

\title{
Seeing the People's Republic of China through the Eyes of Montesquieu: Why Sino-European Collaboration on Eco City Development Suffers from European Misinterpretations of "Good Governance"
}

\author{
Martin de Jong ${ }^{1,2,3}$, Helen Stout ${ }^{3}$ and Li Sun ${ }^{4, *}$ \\ 1 Faculty of Technology, Policy \& Management, Delft University of Technology, Mekelweg 2, \\ 2628 CD Delft, The Netherlands; W.M.deJong@tudelft.nl \\ 2 School of International Relations and Public Affairs, Fudan University, Shanghai 200433, China \\ 3 Erasmus School of Law, Erasmus University Rotterdam, Burgemeester Oudlaan 50, \\ 3062 PA Rotterdam, The Netherlands; stout@law.eur.nl \\ 4 School of Sociology and Social Policy, University of Leeds, Leeds LS29JT, UK \\ * Correspondence: L.Sun2@leeds.ac.uk; Tel.: +44-113-343-4418
}

Academic Editor: Michiel A. Heldeweg

Received: 1 November 2016; Accepted: 6 January 2017; Published: 7 February 2017

\begin{abstract}
China faces a number of impressive challenges in dealing with climate change: rising energy use, growing emission levels of greenhouse gases, dangerous levels of air pollution over cities and low resilience against flood and drought. Sustainable urbanization has been adopted as a keyword in handling these challenges. The Chinese central government has undertaken a variety of measures, including the launch of large Sino-European programs to learn from 'developed nations'. In the wake of these partnerships, a great variety of cross-national and cross-city agreements were signed. Sino-European cooperation does not often run as smoothly as initially hoped because of diverging interests, cultural misunderstandings and practical limitations. In the background, a mismatch in normative conceptions Chinese and European participants have of 'good governance' plays a role. In this contribution, insights taken from Montesquieu's 'The Spirit of Laws' regarding checks and balances and trias politica (updated to 'sextas politica' for the 21st century) are used to comprehend how the exertion of power is distributed and expected to be distributed differently in Chinese than in European administrative traditions. The article will end with conclusions on how European misconceptions of Chinese governance complicate Sino-European collaboration in sustainable urbanization policies.
\end{abstract}

Keywords: sustainable urbanization; Sino-European collaboration; Montesquieu; checks and balances; sextas politica

\section{Introduction}

China is facing a number of impressive challenges in dealing with climate change in the built environment at the same time: its energy use is rising due to the emergence of modern middle class style consumption patterns, it is emitting a growing amount of greenhouse gases, most metropolitan areas suffer from dangerously high levels of air pollution affecting the health of hundreds of millions of people and its resilience against floods in coastal and water-rich areas and against drought in many parts of North China is low. The Chinese government has adopted sustainable urbanization as the most promising approach in handling these challenges, with the hope that economic growth can be sustained while the natural environment is preserved. Finding a suitable response to the impressive speed and rate of urbanization is no easy task. Expanding metropolitan areas should accommodate 
unprecedented numbers of rural people no longer earning enough income from activities in the primary sector (agriculture, fishing, mining) and moving into its cities [1,2] and actions should address the emergence of alarming levels of pollution in water, air and soil in these same cities due to activities in the secondary sector (materials processing, manufacturing and production of end products) [1].

To cope with both of these developments at the same time, the Chinese central government has undertaken a variety of initiatives, including the launching of elaborate national eco city, low carbon city, low carbon eco city, smart city, and sponge city initiatives as well as various other programs to promote sustainable urbanization $[3,4]$. The goal is to encourage local governments to commit themselves to become the national standard in balanced social, economic and environmental urban growth and to use the successful ones among them as demonstration models to be mainstreamed around the country $[3,5,6]$. Most of these cities have committed themselves to drafting sophisticated indicator systems to monitor their progress, revise urban master plans to make their new towns and science parks greener, adopt clean and green technologies and seek international partner countries, provinces and cities to support them in building up their capacity and knowledge base [5,7-9].

Regarding the latter, high bets are placed on the involvement of foreign governments and foreign expertise. Like other 'Asian tigers', Chinese authorities cherish the attraction of investment and expertise from what they consider 'developed countries', i.e., nations in which the availability of advanced technological and planning solutions is presumed [10]. To that effect, China and the EU developed a partnership on climate change in 2005 (renewed in 2015), from which a host of collaborative agreements were signed between Chinese and various European partners. According to European Commission, in 2012, this formula was extended to another high-level partnership on sustainable urbanization, leading to a wave of Sino-European cross-national and cross-city agreements.

To flesh this out in administrative terms, Chinese applicant cities should partner with national or local governments, investors, engineering consultants and high-tech firms from wealthier European countries with a stronger (green and clean) technology base. In some more widely reported eco and low carbon city projects, European involvement has been or is indeed substantial, such as in Qingdao (German partners), Tangshan-Caofeidian and Wuxi (Swedish partners), Shanghai-Chongming-Dongtan (British partners), Beijing-Mentougou (Finnish partners), Shenzhen-Longgang-Pingdi (Dutch partners) and Wuhan-Caidian (French partners). But various scholars have demonstrated that compared to the Sino-Singaporean partnerships in Suzhou, Tianjin and Guangzhou, many of the Sino-European ones have not flown so well, and are certainly not nearly as stable and impactful [3,7-9,11,12]. Although there certainly appears to be variety among the styles, approaches and organizational arrangements chosen by representatives from various European nations (with the German and Swedish governments willing to invest more funds and allowing for more regular institutional structures for collaboration than British, Finns and Dutch for instance), they clearly share a number of features which Asians players do not have.

What transpires from the above referenced studies is that in spite of high stakes and good intentions, Sino-European cooperation often proves more complicated and harder to handle than initially hoped. Hiccups in cooperation have often been colored by unrealistic expectations regarding:

(1) the viability of turn-key technological solutions (ready-made facilities, installations or engineering packages not adapted and contextualized to their new Chinese context);

(2) the possibility to adopt integrated large-scale solutions across often competing policy sectors in China;

(3) the limited willingness and capability among European players to invest large sums of money;

(4) the limited willingness and capability among Chinese players to pay for consultancy services and knowledge rather than physical deliverables;

(5) misconceptions at both sides regarding the value of long term personal relationships in doing business ('contract over contact', or vice versa) and other cultural misunderstandings; and 
(6) misguided European attitudes of superiority and lack of time and effort spent on understanding the complexities of the Chinese context.

It is undeniable that these mismatches and pitfalls appear far more frequently in the interaction between Chinese and European players than they do in Sino-Asian collaboration. Asians are simply more familiar with Chinese features of political and administrative structure and culture and less eager to 'sermon' on political morality and the inherent and universal appropriateness of the solutions they offer.

We argue that, in many cases, underlying these misunderstandings in decent and professional project management for sustainable urbanization is a visceral legal and political conception of 'good governance' that European (and other Western) policy-makers and analysts have adopted at home and unconsciously take with them when going to China to do international projects there. Violation of the ethical norms attached to this conception lead many of them to feel strong moral indignation. In this contribution, we aim to demonstrate that a good part of these implicit assumptions can be derived from central ideas in Montesquieu's seminal 18th century 'The Spirit of Laws'. Charles de Secondat, Baron de Montesquieu et de Brede, was a legal and political philosopher in 18th century France, now primarily known for his ideas on checks and balances and the separation of powers. This part of his ideas were almost seamlessly fleshed out in the American constitution as well as in the first French constitution after the French Revolution, and also partially realized in most modern day European administrative systems. The constitutional and institutional impact of his ideas in Europe is hard to overestimate. Although we do not claim that Montesquieu's view of law and politics is the only one force having profound implications for how Europeans see 'good governance' and 'professional policy-making', we do believe it epitomizes the core beliefs they carry with them in Sino-European collaboration for sustainable urbanization. Much of the confusion has to do with the division of power in political and administrative systems, which is inherently valued by Europeans and rejected by Chinese.

To build up our argument, Section 2 will present Montesquieu's central ideas and assumptions for good governance. We will conclude that these are vital to grasp the subtleties of governance and decision-making in 21st century Europe, but that his 'trias politica' is in need of a serious update. Section 3 transforms it into a 'sextas politica' to include features of more complex administrative systems as they currently exist around the world. Following that, in Section 4 this sextas politica is matched with the Chinese administrative context, which offers intriguing insights as to how expectations regarding 'good governance' and 'constructive collaboration' can diverge between Chinese and European policy-makers, planners and analysts. Section 5 will then apply these lessons to Sino-European collaboration in promoting sustainable urbanization and explain mismatches in expectations regarding good governance from a Montesquieuan viewpoint. Finally, Section 6 will provide a number of lessons on the identified misunderstandings Europeans have of Chinese policy-making and offer suggestions on dealing with them constructively to settle for more successful Sino-European collaboration.

\section{Montesquieu's Central Ideas and Assumptions}

Among the uninitiated, Montesquieu is best remembered for his propagation of the 'trias politica', otherwise known as the separation of powers into a legislative, an executive and a judicial branch. A very usable and practicable design of this separation was developed by the American Founding Fathers and fleshed out to become the foundation of the constitution of the United States based on their interpretation of Montesquieu's work. More particularly, the chapter in which he described the English state system as he saw it served as a model for the American trias politica (Montesquieu SL, Book XI, Chapter VI). Other Western nations around the world later also adopted the key principles behind the separation of powers, but in their case it was the importance of splitting off the judiciary from the legislative and the executive that was deemed the crucial element of reform. Consequently, 
the separation in tasks and functions between the law-giver and law-executer was not elaborated as systematically as it was in the United States.

In recent years, a debate has emerged among Montesquieu experts and adepts to whether he should be seen as an overt or covert proponent of Anglo-Saxon style liberal republicanism or whether he was at heart actually a supporter of French-style liberal monarchy opposing both absolute monarchy a la Louis XIV and republicanism. In his 'The Spirit of Laws', Montesquieu develops a typology of state systems distinguishing despotic, monarchic and republican regimes. In the former, the main driver for the leadership to establish and maintain its position is fear of arbitrary exertion of state power by despots, in the second one it is (selfish) honor that cultivates the elites, officials and kings and in the latter one it is (selfless) civic virtue that cultivates leaders and citizens alike (Montesquieu, SL, Book III). While it is obvious to all observers that Montesquieu saw despotism and absolutism as dangerous for any population's freedom and therefore undesirable, observers part company when it comes to the merits and demerits of the other two. Rahe and his colleagues [13] argue that to avoid censorship in France, in words he praised French monarchy while actually supporting English republicanism 'cloaked as monarchy'. He was himself not very systematic and truthful in the application of his own typology, given the fact that England was a monarchy, but a constitutional one with a strong parliament consisting of two chambers representing different social classes. Probably, Montesquieu's more detailed knowledge of the English practice based on personal visit and observation made him see the limitations of his own typology. Other analysts have retorted that Rahe's arguments are flawed in the sense that Montesquieu certainly did not praise everything he saw in England and was actually more enamored by his own French system provided the power of the Monarch was checked by other public actors. One such example is local 'parlements' acting as legal magistrates endorsing royal edicts (or not) and another is aristocrats operating as a countervailing power against arbitrary interventions against their primus inter pares, the King himself $[14,15]$. Since it is hard to look into the mind of an 18th century author and find out what he truly intended to write, it cannot be 'objectively' established who is right and wrong in this debate. However, it is fairly obvious that Montesquieu rejected pure republicanism, given that it was based on Greek and Roman civic virtues that he believed existed in ancient times, but not anymore in post-medieval Europe. Moreover, he was of the opinion that republics can only thrive in small territories, as was the case with the ancient Green city-states (Montesquieu, SL, Book VIII, Chapter XVI). It is thus also uncertain what he would have thought of the American administrative system, which is often touted as the constitutional fleshing out of his ideas, but very clearly a republic and not a monarchy.

It is perhaps more important to spot the underlying assumptions that Montesquieu adopted when coming to an assessment of the political and legal fairness and economic soundness of administrative systems. In that regard it is important to highlight that political liberty to him, as to any other liberal, was the key value in his thinking. He plainly defined freedom as the absence of fear, implying security and protection of citizens from arbitrary and harmful exercise of power against them by both state organs and fellow citizens (Montesquieu, SL, Book XII). He aimed to guarantee this freedom by means of three constitutional safeguards, these being:

- the existence of countervailing powers within the state itself, to ensure not too much power was concentrated and bundled within one or only a few people or organizations;

- the protection of citizens by rule-of-law, to secure that state bodies and organs would only undertake deleterious infringements on citizen rights if these were backed up by law and only after a minimum of basic civil rights were taken into account when applying these infringements; and

- the political representation of various rungs or strata in society within the various state bodies, as a guarantee that no societal groups would feel alienated from the state that governs them and that these groups could check and balance each other's influence too.

Montesquieu was far from being a radical reformer or a full-fledged democrat. If anything, he was a liberal incrementalist and possibly very happy with the moderate shape French monarchy had 
had before and after Louis XIV and from which he personally benefited in his career. Moreover, he was of the opinion that all nations had their own physical and cultural 'spirit' which was or at least should be reflected in their administrative and legislative frameworks. Here we stumble on an apparent inconsistency. Although he felt that laws and their underlying spirit should match, he did not want to imply that he found all possible administrative systems desirable or acceptable, even if they matched their national spirit. For instance, he explicitly and repeatedly rejected Chinese, Russian, Turkish, Persian, Polish or any other despotism by definition (cf. Montesquieu, Letter 79, Persian Letters, as translated in: [16] (pp. 110-111). Even for despotic regimes, reform away from despotism by introducing more countervailing powers, rule-of-law or more even representation of various societal groups would enhance the freedom of their citizens. After all, from a moral standpoint, he considered despotism as inherently bad, but to the extent that reform was required for the sake of political or legal justice or economic wealth, this should be done in a piecemeal fashion and by subtle inducement rather than hierarchically imposed to allow citizens to get accustomed to their new situation.

Consequently, even though it is, leaning on the above more generic principles as we derive them from 'The Spirit of Laws', easy to see how a good administrative system can (and in fact, should, depending on context) be drafted in various ways, it is also perfectly understandable that the trias politica survives among the public as Montesquieu's greatest intellectual inheritance.

\section{From a Trias Politica to a 'Sextas Politica'}

The world has changed enormously since Montesquieu wrote his masterpiece, and this is especially visible if we go beyond his central ideas and assumptions and apply them to the context of actual administrative structures and cultures in existence in the early 21st century. While the legislative power in European countries in Montesquieu's day could roughly be equaled to state bodies and organs enacting laws of various kinds (especially civil and penal law), the executive (de facto: the King) was responsible for the implementation of international agreements as well as a host of public tasks exerted without or beyond legal support, such as taxation, public works, war and a variety of other tasks. The judiciary would make decisions on individual cases primarily related to civil and penal law. Administrative law hardly existed in those days, and its absence allowed the executive free reign in the performing of public execution and making it the strongest power by far (as for instance expressed in the famous adage "The King can do no wrong"). Most curbs on the concentration of power were therefore addressing (or rather: redressing) the position of the king and his court and bureaucracy, and aimed at keeping them in check from various sides.

Since Montesquieu, the power of the executive has indeed been hemmed in by a variety of developments. Democratization in many parts of Europe has given the legislative branch a much stronger position. It has also prompted a surge of administrative law and rule-of-law has circumscribed, specified and delimited the competencies and discretions of public bodies belonging to the executive branch. Finally, the life-long appointments of many members of the judiciary branch and serious constraints placed on the legislative and executive branches to interfere with verdicts reached by the judiciary has made the value of their independent judgment far more secure than it was before. In that sense, in many Western countries where Montesquieu is known, the trias politica (not a term to be found in 'The Spirit of Laws' itself) has been established at least in spirit, if not in structure. Outside of the West, aspects of it have been adopted, but the influence of his political and legal philosophy and recipes has been much weaker.

However, much more has occurred through the centuries than the gradual rolling out of the separation and balance of powers in constitutional and administrative systems around the world. The role of the state and players around it has also massively transformed due to technological, economic and social changes. These developments have changed the public decision-making landscape dramatically and led to the emergence and rise of a variety of public, semi-public and private bodies involved in decision-making, influencing the role and position of the three first powers and each other, often diluting the power concentration in only a few hands and sometimes tipping the balance in favor 
of one side or another. Although the developments were relatively similar around the world, exactly how they were fleshed out was obviously path-dependent and related to the specific spirit and context of the nation in question. Characterizing and mapping this transformation is complex, but based on a number of sources, we have chosen to portray them as three additional powers that can be added to the list of the first three.

Fourth power: the implementative. Since the sheer number of tasks and functions performed by the state has seen a gradual increase since the 19th century and an impressive expansion since World War II when a shift from the night watchman state to the welfare state occurred, the size of the bureaucracy grew accordingly $[17,18]$. In the 18th, 19th and even early 20th century, kings, emperors and despots and their ministers and courtiers were able to exert a substantial amount of influence over civil servants executing tasks on their behalf. In the course of the 20th and into the 21st century however, the ministries and agencies affiliated with them grew to such enormous proportions, along with the detailed expertise, knowledge and information they had the disposal of, that the formal leadership of the bureaucracy was no longer practically capable of controlling their power. In consequence, sometimes formally but more often informally, the bureaucracy emerged as a separate fourth power [19]. When ministers, as the officials responsible in name for operations happening within their ministries, the modern executive, were held accountable in Parliament, the modern legislative, they often had to admit they were unable to control actions undertaken in their name [20]. We choose to dub this fourth power the 'implementative'. Implementation of public tasks by public bodies and organs is not merely a detailed technical task that can be seen as an automatic or logical step to execute the will of the executive power. In practice it requires many specific choices, some of which are also political in nature, and many of which can be seen as the exertion of technocratic exertion of power: the public bureaucracy has become a fourth power in and of itself potentially curbing the power of the first three.

Fifth power: the consultative. Not only has the number of tasks the state performs grown enormously, so has their social, economic and technical complexity. Some of the expertise, knowledge and information required for fulfilling these tasks well is available within the bureaucracy itself, but not all. If it is very specific and specialized, it may not be possible or worthwhile for bureaucracies directly to employ relevant people, but rather to hire from outside sources. Jasanoff has called this complex of counselors, advisors, experts, consultants and lobbyists the 'fifth branch' [21]. These specialized informers of public policy can hail from a variety of sources. Some of them work for the public sector, but have a somewhat independent or impartial position within it, such as advisory councils or offices. Some come from universities, research institutes or think-tanks. Others represent private research organizations, consultancy firms and are occasionally paid good money for their services. Still others simply act as lobbyists on behalf of various interest organizations promoting their cause among public officials working for the first, second, and fourth power (for the third power only under particular conditions). In nearly all of these cases of providing help and advice, there are value-laden and political aspects involved alongside the content-related specific knowledge provided [22]. Put otherwise, advice and consultancy for the public sector explicitly or implicitly concerns the exertion of power. Dependency on this expertise, knowledge and information constrains the power concentration among the first four powers. This is why we call our fifth power the 'consultative'.

Sixth power: the commentative. Information provision to the wider population in the days of Montesquieu was quite limited simply because of technical limitations. Many of the media that are known and impactful in the 21st century are of fairly recent date. Apart from rumors and public announcements, citizens now also use newspapers and magazines, radio and television, websites and social media to collect information and develop opinions about public decision-making and make up their minds on what their position is vis-a-vis the exertion of state power. In quite a number of contexts, the influence of the media in commenting on actions planned or undertaken by the various segments of the public sector has been such that policies can be adopted, adapted or aborted, reputations of public 
officials built, bent or broken and the position of the previous five powers substantially influenced. The increasingly powerful role of the public relations consultant is a major factor in today's political process [23]. Some analysts have pointed to this influence in some countries as being tantamount to 'mediacracy' or 'democrature' $[24,25]$, but it has also been observed that especially in other countries the media more often act as a mouthpiece of the government and therefore hardly constitute a power of their own. Across the board, however, we feel their presence and impact on state actions in the 21st century justifies the name sixth power, that is a 'commentative' branch able to act as a set of players influencing the way the previous five pillars exert their power.

Although the characterization of the state as consisting of six mutually correcting powers (sextas politica) is admittedly only a stylized version of what administrative systems around the world look like, we believe it is largely in conformity with how political and policy scientists have sketched the evolution of the public sector and public decision-making and in line with how Montesquieu himself would likely have analyzed the current legal, political and administrative situation. The question now is whether we can identify essential differences between the way in which the 'sextas politica' operates in Western countries and in China.

\section{Sextas Politica in China?}

At first sight, Montesquieu's verdict on dynastic China was unambiguous: people were driven by fear as their key emotion, because it was ruled by absolutist emperors who ruled the country as despots [26]. In their exertion of power, these emperors were unfettered by any counterbalancing forces, players or people. In that sense, China to him ended up in the same despotic box as Poland, Russia, Persia, India, Japan and a host of other Oriental nations where more favorable and citizen-friendly administrative structures did not exist nor had a chance of being realized. Since Montesquieu never made any trip to the 'East' and based his analyses on famous Western historical sources (the accuracy of which is doubtful $[27,28]$ ), we should qualify his view of China as 'orientalist' [29]. We should add that at various places in 'The Spirit of Laws' he also showed respect and admiration for the sophistication of customs, rituals, ceremonies and routines in China, which at least gave it the shape of a very sophisticated form of despotism (Montesquieu, SL, Book VIII, Chapters VII, XXI). Nonetheless, there was no doubt that back in those days, China was indeed an unlikely candidate for the introduction of any form of checks and balances or separation of powers.

As we know, the dynastic China of inherited positions has been replaced with that of the People's Republic of China, where the line of Chinese Communist Party is supposed to prevail in governance and policy-making and permeate all sectors and levels of the administrative system. Not only has a parallel party hierarchy been built next to all governmental bodies to infuse them with ideological and programmatic guidance, but party cells have also been established in the midst of all public and some private organizations to bring them in line with the wishes of the Communist Party [30]. It is not easy to state whether levels of power concentration are currently higher or lower in China than they were a few centuries ago, but it is beyond any doubt that both the spirit and the laws of the People's Republic of China are not terribly favorable for the introduction of any 'trias politica' or 'sextas politica'. Chinese political and administrative culture, based as it is on a mixture of Confucian, legalist and Communist values can generally be characterized by a desire for order, control and uniformity, respect for hierarchy, appetite for practical rather than theoretical wisdom, importance attached to a mixture of educational achievement and meritocracy on the one hand and personal loyalty and factionalism on the other, and stronger attachment to family than to civic virtues [31-37]. The above factors are neither particularly conducive to the adoption of checks and balances nor to the sheltering of citizens from autocratic power nor to the safeguarding of any form of separation of powers.

Although China is not a representative democracy, various regions and sections of society are consulted annually in the preparation of new policies by means of the National People's Congress (NPC) and the Chinese People's Political Consultative Conference (CCPPC) when the two political bodies are convened each spring. The NPC is officially the highest representative body in the nation, 
while the CСРPC offers suggestions regarding existing societal problems as they are experienced in the regions. In practice it is the 25-member Politburo of the Central Party Committee (CPC) and the 9-member Standing Committee that exert by far the greatest legislative influence. That this influence can be so extensive is to a large extent due to these members occupying key positions in various executive bodies such as the State Council (equal to Cabinets in some Western countries), the People's Liberation Army and a great variety of governmental bodies. In practice the osmosis between party and government positions is enormous with a relatively small number of people controlling extensive personal and organizational networks and exerting a great amount of power. At that level, power struggles occur more frequently among various factions headed by rival leaders within the Party and nowadays factionalism tends to prevail over content-related or ideological disagreement. This aspect of Chinese governance is further strengthened by upward mobility of lower officials being based on nomenclature promotion systems. Career advancement is controlled by higher officials applying economic and environmental performance standards, alongside personal and party loyalty $[38,39]$. In short, to the extent that in such a personalized and osmotic institutional system a separate legislative and executive can be discerned at all, it is obvious that the executive prevails strongly and that due to long years of party socialization, variety in the expression of voices is limited.

Nominally, the judiciary is recognized as a separate branch of government with its own task. However, judges in China are invariably CCP members expected to show loyalty to the party line and their decisions are not automatically respected and accepted by executive bodies operating at hierarchical levels equal or superior to them. In other words, party loyalty, personal loyalty and hierarchical level of governance matter more than judicial impartiality and independence. Citizens simply cannot take recourse to the law for granted and the exact meaning of rule-of-law is therefore questionable, partly due to the fact that historically in Chinese legalism use of the law was aimed at providing law as in instrument of power in the hands of their leadership to control society rather than the other way around $[40,41]$.

As in Europe, the executive branch of government has expanded dramatically and spread out into large committees, ministries and agencies under the supervision of ministers and vice-ministers who are also part of the CCP establishment. Under them, thousands of civil servants work on the actual implementation of the more generic 'framework' decisions adopted by the executive. In some sense, one could claim that the bureaucracy like in Europe has evolved into a force to be reckoned with, but there are a few reasons why the Chinese 'implementative' acts less as an independent fourth power: cross-sectoral interaction below the level of ministers is minimal, hierarchical control from the top down is enforced much more strictly (and initiative from the bottom accordingly discouraged) and lateral party-guidance also reduces the autonomy of bureaucrats [42-44]. Whether the bureaucracy in China can be effectively be seen as a fourth power is therefore questionable.

Much of the same applies to the 'consultative'. The need for specialized expertise and advice is undeniable and fulfilled mostly through specialized public advisory agencies and professors from top level universities, but the networks through which these are provided tend to be more politicized and personalized than in Europe. In this relationship, the political and administrative officials normally act as the dominant party with the analysts and advisors delivering the insights and data wished by their political and administrative clients [45]. These relations exist primarily between the executive and the consultative and rarely with any of the other powers.

Finally, relatively more is known about the position of the 'commentative' as the sixth power in China. In the 2014 worldwide index of press freedom, China was ranked 175 out of 180 countries [46]. Among the various segments of the media, the independence of the publishers of books, magazines and newspapers is known to be strictly curtailed by censorship from within the executive: the State Administration of Press, Publication, Radio, Film and Television of the People's Republic of China is the monitoring body, while communication through social media channels is controlled to a lesser extent and more ex post, but the freedom of information exchange on the internet is also severely curtailed. Here, the Central Leading Group for Internet Security and Informatization is the implementation body 
for internet-related issues; it is directly supervised by the Central Committee of the CPC. In no way can the commentative therefore be seen as a sixth power within the administrative system.

In sum, although it is conceivable and potentially useful to analyze the functioning of the Chinese administrative system in terms of a sextas politica, the fragmentation among these six powers is far more limited than in Western democracies and the influence of the executive profoundly permeates all five other powers Table 1 illustrates this for the national level, and it also applies to the various local levels including provincial, prefectural, county, township, and village level.Moreover, the alignment of all government action with the precepts of the party line, the personalized factionalism crossing organizational boundaries and the deference of officials and employees to the position and influence of a small number of key people at the apex create an institutional environment where countervailing or separated powers are unlikely to thrive, in theory and especially in practice. A sextas politica may have its relevance as an updated of version of Montesquieu's 'The Spirit of Laws' in Western nations which he considered suitable for monarchy or republicanism. However perniciously orientalist his view and description of China may have been, application of his line of thought to modern Chinese governance does not alter the notion that the power of the party leadership prevails over that of all other players and that citizens enjoy less protection from their government than they do in Europe. When seeing China's current administrative system through a Montesquieuan lens, it will almost automatically appear as modern despotism. That would lead many Europeans to draw orientalist conclusions on how policy-making in China works, but one might expect that Westerners involved in Chinese decision-making regarding eco and other sustainable cities anticipate this difference in governance traditions when doing business with Chinese policy-makers, planners and analysts. Do they?

Table 1. Chinese administrative system for eco city development seen as sextas politica.

\begin{tabular}{|c|c|c|c|c|c|}
\hline $\begin{array}{c}\text { Commentative (Sixth } \\
\text { Power) }\end{array}$ & $\begin{array}{c}\text { Legislative } \\
\text { (First Power) }\end{array}$ & $\begin{array}{c}\text { Executive } \\
\text { (Second Power) }\end{array}$ & $\begin{array}{l}\text { Implementative } \\
\text { (Fourth Power) }\end{array}$ & $\begin{array}{c}\text { Consultative (Fifth } \\
\text { Power) }\end{array}$ & $\begin{array}{c}\text { Judicial } \\
\text { (Third Power) }\end{array}$ \\
\hline $\begin{array}{l}\text { State Administration } \\
\text { of Press, Publication, } \\
\text { Radio, Film and } \\
\text { Television; } \\
\text { Central Leading Group } \\
\text { for Internet Security } \\
\text { and Informatization }\end{array}$ & $\begin{array}{c}\text { Central } \\
\text { Committee of the } \\
\text { Central Party } \\
\text { Committee; } \\
\text { National People's } \\
\text { Congress }\end{array}$ & $\begin{array}{l}\text { State Council; } \\
\text { Ministers and } \\
\text { Vice-Ministers } \\
\text { (e.g., NDRC, } \\
\text { MOHURD, MEP, } \\
\text { MLR, MOF) }^{1}\end{array}$ & $\begin{array}{l}\text { Ministries (see under } \\
\text { second power) } \\
\text { Local governments } \\
\text { State owned } \\
\text { enterprises }\end{array}$ & $\begin{array}{c}\text { Chinese People's } \\
\text { Political Consultative } \\
\text { Conference Think } \\
\text { Tanks }{ }^{2} \text { Universities } \\
{ }^{3} \text { Research Institutes } \\
\text { under Ministries }{ }^{4}\end{array}$ & $\begin{array}{c}\text { Supreme } \\
\text { People's Court } \\
\text { Supreme } \\
\text { People's } \\
\text { Procuratorate }\end{array}$ \\
\hline
\end{tabular}

${ }^{1}$ National Development and Reform Commission (NDRC), Ministry of Housing and Urban-Rural Development (MOHURD), Ministry of Environmental Protection (MEP), Ministry of Land and Resources (MLR), Ministry of Finance (MOF); ${ }^{2}$ Such as the Development Research Center of the State Council; Chinese Academy of Social Sciences; Chinese Academy of Science; ${ }^{3}$ Such as Peking University; Tsinghua University; ${ }^{4}$ Such as China Academy of Urban Planning and Design under Ministry of Housing and Urban-Rural Development.

\section{How Europeans in Sino-European Collaboration See the PRC through a Montesquieuan Lens}

The first author of this article now has approximately seven years of experience in eco and low carbon city development in China. This has been (1) hands-on policy-making and advisory experience in Shenzhen International (formerly Sino-Dutch) Low Carbon City; (2) knowledge exchange realized through membership of the Chinese Eco City Council and the International Eco City Network; and (3) participation in a great number of workshops and conferences on eco city development in China in general and Sino-foreign collaboration in particular. Many of his observations are reflected in international publications on the topic $[3,6,8,47,48]$. Observations below are primarily based on these abovementioned events.

European civil servants, investors, engineering consultants, architects and other advisors and participants in Sino-European collaboration on sustainable urbanization come to China with particular expectations regarding the benefits of their involvement. Some come with idealistic motives to build 
more ecologically friendly cities and save the planet. Some come to establish fruitful and productive networks of collaboration for research and advice. Some come to develop and sign Memorandums of Understanding and agreements between ministries, cities or other public bodies. Many appear with the hope of earning good money and sharing in the spoils of China's huge investments in real estate and urban infrastructures. Most come with the idea that several of the above are within reach, but none of them are totally blank in terms of what they consider 'good governance'. They all come with the awareness that sustainable urbanization is a top priority for the Chinese government and that the transfer of technical, economic and environmental expertise is highly appreciated. Obviously, there is the awareness that planning and decision-making in China differ markedly from the way things are done in Europe, but the exact ramifications of the absence of representative democracy, weak functioning of rule-of-law, prevalence of the $\mathrm{CCP}$, the media acting as mouthpiece of dominant forces within that party, the crucial importance of personal networks among a small number of extremely influential officials and the impressive speed of decision-making are normally not considered. However, when their deeply felt Western values on 'good governance' are accidentally or purposively violated in Sino-European collaborative projects, the result is often disdain, indignation and/or a deep concern to get embroiled in unethical practices and having one's reputation back home compromised as a result.

We argue that most EU participants in joint Sino-European projects promoting sustainable urbanization in China unconsciously judge the country following Montesquieuan standards. Awareness of this phenomenon can prove quite helpful in clarifying their feelings of inconvenience and embarrassment, since the fundamentals in Montesquieu's take on sound constitutional and institutional systems and ethically sound policy-making is profoundly embedded in assumptions and assessments that Europeans and other Westerners have come to adopt in the course of centuries. For the initiated, this may have been explicit and conscious adoption, for others their emotional embrace may be implicit and unconscious, but nonetheless with the same powerful moralizing effect.

As mentioned in Sections 2 and 3, the underlying value promoted in Montesquieu's work is in fact one of segmentation and fragmentation. Absolute power in the hand of one or a few is undesirable and hazardous, various strata or classes in society should find representation within the state and citizens deserve a government applying rule-of-law based interventions to avoid arbitrary infringement of anybody's established rights. Separation of powers is a logical derivative from these assumptions, and representative democracy is a possible one that Montesquieu himself did not promote. Although the practical fleshing out of these underlying ideas in modern day governance is open to debate and although we have claimed that the trias politica requires a conceptual update to be applicable in the 21st century, European political culture is imbued with Montesquieuan expectations regarding good governance. Deviation from them leads to profound emotional unease.

Yet, neither China's political-administrative structure nor its political-administrative culture were ever based on Montesquieuan foundations and, as we could observe in Section 4, their systematic application to Chinese governance would lead any analyst to conclude that a great many imperfections exist. The CCP holds core positions in all of the six powers and essentially controls them. Public and private players live in deep osmosis with each other blurring the boundaries between the budget and market mechanisms. Citizens losing their land in the course of urban expansion or renewal can never be sure whether a judge will grant them adequate compensation based on impartial judgment [49]. Among the six powers, the several organs of the executive clearly dominate all the others. The task of the legislative is to ensure that the 'right key people' are selected for the executive. The public representatives in the judiciary are appointed by and answerable to superiors within the executive and there is no guarantee that their verdicts and decisions are respected by executive organs. The implementative is rather submissive to its political executive masters. The consultative walks in the slipstream of the executive and generates the correct information and data. And the employees within the commentative mimic the wishes of its executive overlord, ensured by mechanisms of ex ante and ex post censorship. However different the PRC may be from imperial China, concentration of power, 
deference to hierarchy, political inequality, factional connivance, citizens relying on petitioning rather than democratic representation to push their cause, bureaucratic officials caught between political meritocracy and political loyalty, respectful experts systematically teaming up with political superiors and following their demands and docile commentators living between self-censorship and censorship are perennial features of governance in China. These features almost naturally clash with expectations that emerge from a Montesquieuan perspective of good governance. This may give Europeans an impression of deeply ingrained injustice, but the values underlying these Chinese features have existed for millennia and judging them by Montesquieuan standards may then be asking wrong questions and addressing irrelevant issues (in Chinese eyes).

When it comes to collaboration promoting sustainable urbanization, the odds are that tensions within Sino-Asian projects will be less pronounced than in Sino-European ones. Other Asian countries derive their political and administrative culture either from the same Confucian and legalist roots, but overlaid with enlightened autocratic rule (Singapore), a Montesquieuan superstructure (Japan, South Korea), or a Communist superstructure (Vietnam, Mongolia), which at least narrows the gap in political-administrative values and facilitates interaction. In the case of Sino-European collaboration, both the philosophical roots and the constitutional and institutional superstructure diverge enormously, making the likelihood of mismatches far higher. European participants feel awkward when very few people are eventually at the helm, when stakeholders are not 'consulted', when public players invest in private projects or vice versa, when contacts rather than contracts prevail for the granting of construction jobs, when the most courageous legal contestants are the most likely losers, or when officials look up to Beijing rather than down to the electorate for success criteria. They find it tedious when journalists hang on to the very words of politicians they are supposed to report on, when experts and consultants seem to have no opinion of their own, and when lower level civil servants sit second rank behind their superiors rather than next to them. They may even feel anger coming up when might and right coincide, when their own intellectual ideas are ground through a coffee machine and remolded in ways they do not recognize, when delivering products and services and being paid for them appear two different things, when they themselves appear mainly for the show and when economic interests continue to eclipse ecological ones in spite of official rhetoric in favor of the opposite. And yet this is the most probable experience they will undergo when they engage in joint Sino-European sustainable urbanization projects. It is therefore unsurprising that their 'Montesquieuan mindset' makes them vulnerable to confusion and frustration in the East. This is not because this mindset is wrong, but because lack of awareness that one has the mindset and that its relevance may elide universal validity leads to ethnocentrism, fragility and possible failure. Consciousness of the Montesquieuan under-layer in their political morality and the capability to consider whether deviation from it in given alien circumstances can be made responsibly and respectably and can contribute to finding a remedy against high hopes and disappointing results in delivering Sino-European collaborative projects.

\section{Conclusions}

In 2011, Dutch architect John van de Water published his book 'You cannot change China, China changes you', specifically targeting a Western audience and aiming to dash its hope in civilizing the former Middle Kingdom [50]. Chinese policy-makers are certainly interested in transforming their nation into something more advanced, sophisticated and modern than they think it is now. They therefore highly value the transfer of various forms of technical and economic expertise, but they adamantly reject any political and legal advice of a nature that Europeans consider inherently ethically sound. This is even the case in policy areas where dramatic reform is urgently needed, such as sustainable urbanization.

In this contribution, we claim that central ideas in Montesquieu's work on 'The Spirit of Laws' regarding political liberty, checks and balances and separation of powers (whether this be in three branches as in the baron's days or in six branches as we believe to be close to the current situation) 
have deeply colored European morality and expectations on good governance. European participants in Sino-European projects in sustainable urbanization and energy transition usually take this morality with them when going to China and experience hardship when they see these values clash with Chinese policy realities. We claim it would be erroneous to suspect that this divergence is merely due to having a Communist political system in place and that unwillingness to undertake structural reform should be blamed for this clash. In fact, the Chinese political and administrative traditions as they exist now are also built on far more ancient and deeply ingrained Confucian and legalist foundations. The confluence of Confucianism, legalism and Communism, which Pye has dubbed 'Confucian Leninism', promotes political values almost diametrically opposed to those of fragmentation, division and individual autonomy [31]. As leaders in a former and potentially future Middle Kingdom, Chinese policy makers can easily afford to ignore such well-intentioned, but unwelcome input. In fact, they are even unlikely to share the cultural values on which these ideas are based, even if at first sight they react sympathetically to them.

To frame it in Montesquieuan terms, one can describe the Chinese administrative context as one of power concentration among a limited number of people in the executive branch and obedient attitudes at the receiving end of all other branches of power. Chinese may not like the Montesquieuan framing qualification of their system as 'despotic' as such, but they are in fact unlikely to reject the ethical implications of such a system. They may well retort by asking Europeans why institutional fragmentation and indecision are superior to a stable political order and determination, or why political liberty should be preferred over social responsibility. European advisors are unlikely to fundamentally change China, but China may well change those same European visitors. Greater judgmental caution and preliminary awareness of the difference in cultural values are due if learning processes during the collaboration are to evolve in conscious and constructive ways. Participants in Sino-European projects ignore this powerful message at their own peril.

Acknowledgments: The authors are indebted to Negar Noori and two anonymous reviewers for valuable suggestions given to an earlier draft of this article.

Author Contributions: First author Martin de Jong is the architect of the key line of thought and most of the writing in this contribution. Second author Helen Stout verified and added to legal and historical aspects of Montesquieu's thinking. Third author Li Sun verified and added to institutional aspects of the administrative system in China and was in charge of the submission process.

Conflicts of Interest: The authors declare no conflict of interest.

\section{References}

1. World Bank. Urban China: Toward Efficient, Inclusive, and Sustainable Urbanization. 2014. Available online: https://openknowledge.worldbank.org/handle/10986/18865 (accessed on 2 August 2016).

2. OECD. OECD Urban Policy Reviews: China 2015. Available online: http://www.oecd-ilibrary.org/urbanrural-and-regional-development/oecd-urban-policy-reviews-china-2015_9789264230040-en (accessed on 4 June 2015).

3. De Jong, M.; Yu, C.; Joss, S.; Wennersten, R.; Yu, L.; Zhang, X.; Ma, X. Eco city development in China: Addressing the policy implementation challenge. J. Clean. Prod. 2016, 134, 31-41. [CrossRef]

4. Yu, L. Low carbon eco-city: New approach for Chinese urbanisation. Habitat Int. 2014, 44, 102-110. [CrossRef]

5. Joss, S.; Molella, A.P. The eco-city as urban technology: Perspectives on Caofeidian international eco-city (China). J. Urban Technol. 2013, 20, 115-137. [CrossRef]

6. De Jong, M.; Wang, D.; Yu, C. Exploring the relevance of the eco-city concept in China: The case of Shenzhen Sino-Dutch low carbon city. J. Urban Technol. 2013, 20, 95-113. [CrossRef]

7. Chang, I.-C.C.; Sheppard, E. China's eco-cities as variegated1 urban sustainability: Dongtan eco-city and Chongming eco-island. J. Urban Technol. 2013, 20, 57-75. [CrossRef]

8. De Jong, M.; Yu, C.; Chen, X.; Wang, D.; Weijnen, M. Developing robust organizational frameworks for Sino-foreign eco-cities: Comparing Sino-Dutch Shenzhen Low Carbon City with other initiatives. J. Clean. Prod. 2013, 57, 209-220. [CrossRef] 
9. Miao, B.; Lang, G. A tale of two eco-cities: Experimentation under hierarchy in Shanghai and Tianjin. Urban Policy Res. 2015, 33, 247-263. [CrossRef]

10. Shwayri, S.T. A model Korean ubiquitous eco-city? The politics of making Songdo. J. Urban Technol. 2013, 20, 39-55. [CrossRef]

11. Hult, A. Swedish production of sustainable urban imaginaries in China. J. Urban Technol. 2013, 20, 77-94. [CrossRef]

12. Chang, I.-C.C.; Leitner, H.; Sheppard, E. A green leap forward? Eco-state restructuring and the Tianjin-Binhai eco-city model. Reg. Stud. 2016, 50, 929-943. [CrossRef]

13. Carrithers, D.W.; Mosher, M.A.; Rahe, P.A. Montesquieu's Science of Politics: Essays on the Spirit of Laws; Rowman \& Littlefield Publishers: Lanham, MD, USA, 2001.

14. Levy, J.T. Montesquieu's Constitutional Legacies; SUNY Press: New York, NY, USA, 2009.

15. De Dijn, A. Was Montesquieu a Liberal Republican? Rev. Politics 2014, 76, 21-41. [CrossRef]

16. Mauldon, M.; Kahn, A. Persian Letters; OUP: Oxford, UK, 2008.

17. Chirot, D. How Societies Change; Sage Publications: London, UK, 2011; Volume 1.

18. Tanzi, V.; Schuknecht, L. Public Spending in the 20th Century: A Global Perspective; Cambridge University Press: Cambridge, UK, 2000.

19. Meier, K.J. Politics and the Bureaucracy: Policymaking in the Fourth Branch of Government; Wadsworth Publishing: Belmont, CA, USA, 1987.

20. Terry, L.D. Leadership of Public Bureaucracies: The Administrator as Conservator; Routledge: London, UK, 2015.

21. Jasanoff, S. The Fifth Branch: Science Advisers as Policymakers; Harvard University Press: Cambridge, MA, USA, 2009.

22. Fischer, F. Technocracy and the Politics of Expertise; SAGE Publications: London, UK, 1990.

23. Cutlip, S.M. The Unseen Power: Public Relations: A History; Routledge: London, UK, 2013.

24. Franson, M.A.H. Démocrature: Comment les Médias Transforment la Démocratie; Editions Aubier: Paris, France, 1992. (In French)

25. Keane, J. Democracy and Media Decadence; Cambridge University Press: Cambridge, UK, 2013.

26. Liu, C. On the Art of Ruling a Big Country: Views of Three Chinese Emperors; Australian National University Press: Canberra, Australia, 1974.

27. Shackleton, R. Montesquieu a Critical Biography; Oxford University Press: Oxford, UK, 1961.

28. Gascar, P. Montesquieu; Flammarion: Paris, France, 1989; Volume 7. (In French)

29. Said, E.W. Orientalism: Western Conceptions of the Orient; Penguin: London, UK, 2001.

30. Zeng, J. The Chinese Communist Party's Capacity to Rule: Ideology, Legitimacy and Party Cohesion; Springer: New York, NY, USA, 2015.

31. Pye, L.W. The Spirit of Chinese Politics; Harvard University Press: Cambridge, MA, USA, 1992.

32. Pye, M.W.; Pye, L.W. Asian Power and Politics: The Cultural Dimensions of Authority; Harvard University Press: Cambridge, MA, USA, 2009.

33. De Jong, $\mathrm{M}$. The pros and cons of Confucian values in transport infrastructure development in China. Policy Soc. 2012, 31, 13-24. [CrossRef]

34. Angle, S.C. Sagehood: The Contemporary Significance of Neo-Confucian Philosophy; Oxford University Press: Oxford, UK, 2009.

35. Bell, D.A. The China Model: Political Meritocracy and the Limits of Democracy; Princeton University Press: Princeton, NJ, USA, 2015.

36. Liu, T.; Sun, L. Pension Reform in China. J. Aging Soc. Policy 2016, 28, 15-28. [CrossRef] [PubMed]

37. Liu, T.; Sun, L. An apocalyptic vision of ageing in China. Z. Gerontol. Geriatr. 2015, 48, 354-364. [CrossRef] [PubMed]

38. Shih, V.; Adolph, C.; Liu, M. Getting ahead in the communist party: Explaining the advancement of central committee members in China. Am. Political Sci. Rev. 2012, 106, 166-187. [CrossRef]

39. Lin, Y.; de Jong, M. Moving up the Hierarchy: Kinship and career advancement in a Chinese township. J. Contemp. China 2016. [CrossRef]

40. Chan, W.-T. A Source Book in Chinese Philosophy; Princeton University Press: Princeton, NJ, USA, 2008.

41. Lieberthal, K. Governing China: From Revolution through Reform; WW Norton: New York, NY, USA, 1995.

42. Cai, Y. State and Agents in China: Disciplining Government Officials; Stanford University Press: Redwood City, CA, USA, 2014. 
43. Sun, L.; Liu, T. Injured but not entitled to legal insurance compensation-Ornamental institutions and migrant workers' informal channels in China. Soc. Policy Adm. 2014, 48, 905-922. [CrossRef]

44. Sun, L.; Liu, T. Occupational diseases and migrant workers' compensation claiming in China: An unheeded social risk in asymmetrical employment relationships. Health Sociol. Rev. 2016, 25, 122-136. [CrossRef]

45. Mu, R.; Mouter, N.; de Jong, M. Strategic Use of Analytical Information in Transport Planning in China: How Is It Different from Western Democracies? J. Urban Technol. 2016. [CrossRef]

46. Xu, B. Media Censorship in China. 2015. Available online: http://www.cfr.org/china/media-censorshipchina/p11515 (accessed on 15 August 2016).

47. De Jong, M. China's art of institutional bricolage: Selectiveness and gradualism in the policy transfer style of a nation. Policy Soc. 2013, 32, 89-101. [CrossRef]

48. Mukhtarov, F.; de Jong, M.; Pierce, R. Political and ethical aspects in the ethnography of policy translation: Research experiences from Turkey and China. Environ. Plan. A 2016. [CrossRef]

49. Van Rooij, B. Regulating Land and Pollution in China: Lawmaking, Compliance, and Enforcement: Theory and Cases; Amsterdam University Press: Amsterdam, NY, USA, 2006.

50. Van de Water, J. You Can't Change China, China Changes You; 010 Publishers: Rotterdam, The Netherlands, 2012.

(C) 2017 by the authors; licensee MDPI, Basel, Switzerland. This article is an open access article distributed under the terms and conditions of the Creative Commons Attribution (CC BY) license (http:/ / creativecommons.org/licenses/by/4.0/). 